\title{
Alessia Damonte*
}

\section{Toward a Better Fiscal Governance?}

\author{
Why the Italian budget has been kept irresponsible, \\ and how the last reforms could make a difference
}

\begin{abstract}
Despite many reforms, evidence from the past decade proves the Italian fiscal policy still being "irresponsible." The article understands the problem from a public choice perspective: irresponsibility is a natural result of unconstrained "raw politics," yet proper institutional designs can bring it under control. It then presents qualitative data showing how Italian irresponsibility follows inappropriate constraints, and explains why the recent European provisions can support a fruitful institutional change.
\end{abstract}

Keywords: evaluation; fiscal governance; fiscal irresponsibility; Italy; performance budgeting.

\section{Introduction}

In 1997, The Economist noted how "Italy had indeed changed: it would do anything - even accept unpleasant budgets - to prove its Euro-worthiness; and, with a little bit of presidential prestidigitation, it had put government instability back into the box of nasty, first-republic memories, along with corruption, jobs-for-theboys and public profligacy." In those years, the requisites to join the Euro-area justified a fiscal discipline as domestically painful as internationally convincing: the expectations of Italian solvency, portrayed by the interest rates on the sovereign debt, aligned to those of the sounder partners and remarkably improved, reaching their best point in 2005 (Figure 1).

Yet, in the second half of the 2000s international investors went back to discriminating among sovereign debts; and Italy grouped with Greece, Portugal, Ireland and Spain into the "PIIGS", the Euro-countries at higher risk of

*Corresponding author: Alessia Damonte, Department of Social and Political Sciences, Università degli Studi di Milano, e-mail: alessia.damonte@unimi.it 


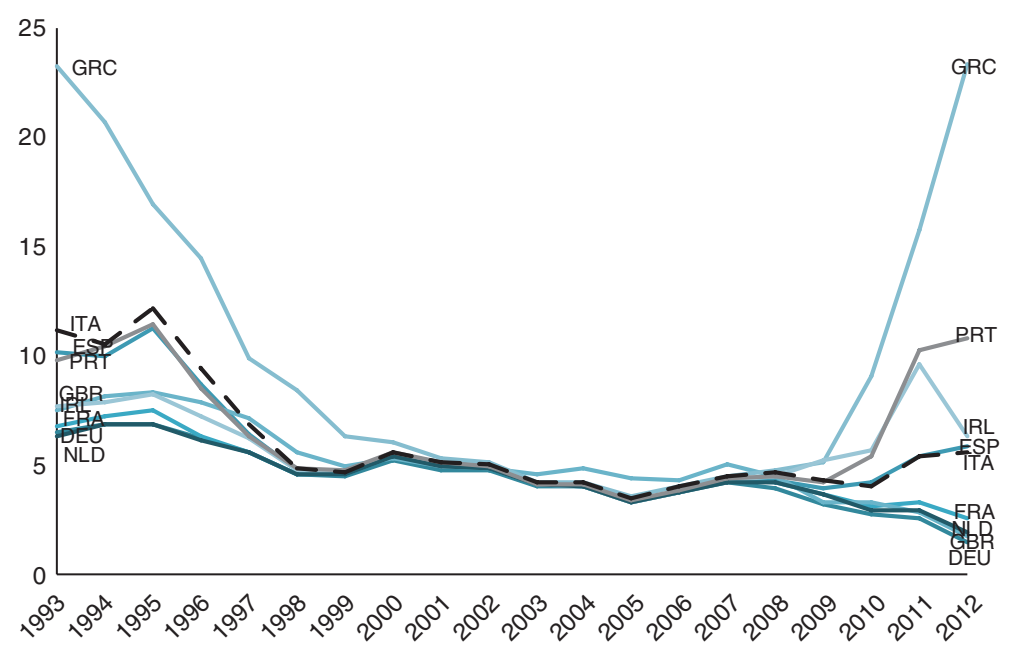

Figure 1: Interest Rates on Sovereign Debts, Selected Countries. Note: Interest rate annual average, 10-year bonds.

Source: Elaboration of data from the European Central Bank.

insolvency. Rising interest rates mirrored the European concerns for the capability of the Italian economy and, before, of its fiscal policy to meet the requirements of the good partnership to the Euro-area as laid down in the Stability and Growth Pact. ${ }^{1}$ Indeed, since 2005 the Commission opened the Excessive Deficit Procedure against Italy twice, because of its increasing debt well above the limit of the $60 \%$ of the GDP and a deficit-to-GDP ratio above the threshold of the 3\%.

Such concerns seem even more legitimate if we look at the Italian budget from a different perspective than the European performance criteria of debt which governments usually claim to have inherited - or of deficit - which focuses on the balance sheet yet misses the underlying strategy.

The dynamics of revenues and expenditures of the public sector (Figure 2) provide such a different viewpoint. The Figure shows how the public sector spending had been constantly increasing until 2010, while the gap between revenues and expenditures had been mainly addressed from the revenue side. Also, the estimated revenues often proved remarkably optimistic.

The Italian governments' bias towards the best case scenario was not limited to revenues. Before, it could be found in the very same data about the economic growth rate, annually calculated for a time span of 3 or 5 years (Figure 3 ).

1 See SEC (2006) 235 fin., SEC (2007) 67 fin., SEC (2008) 105 fin., SEC (2009) 233 fin., SEC (2010) 293 fin., SEC (2011) 810 fin., COM (2012) 318 fin. 


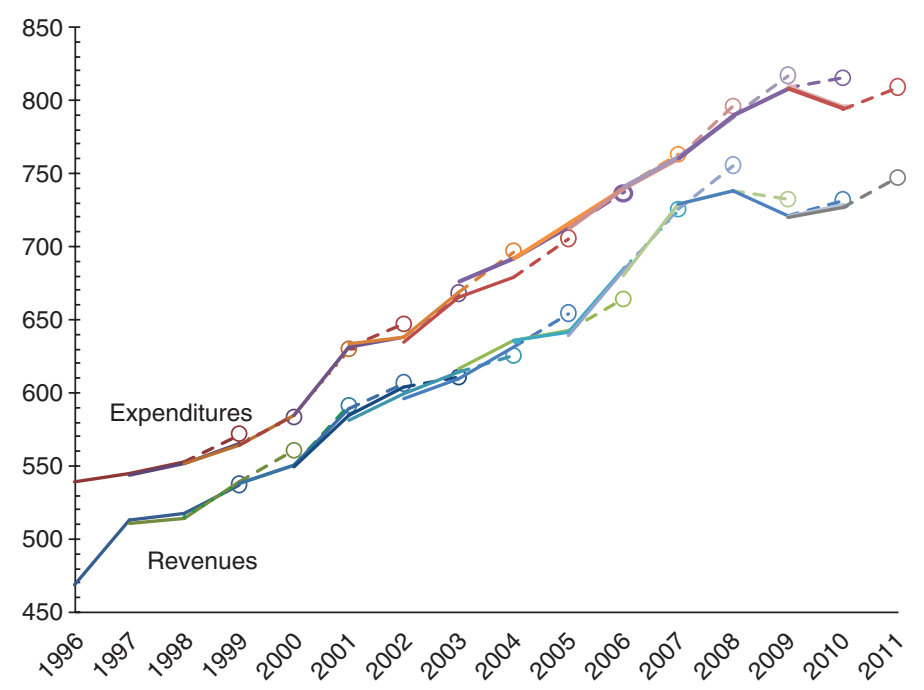

Figure 2: Italy's Public Sector: Revenues and Expenditures (bln Euros at market prices). Keys: Solid lines=consolidated values; dashed lines=estimated values; empty dots=estimated value of reference for the financial decision.

Note: The concept of public sector includes the central and the local agencies, the social security funds, and all those units which meet the requisites defined by the Regulation CE 2223/96 and following modification. In Italy, after Law no. 311 of 2004, the precise boundary is defined by the National institute of statistics (Istat) which yearly publishes the list of included bodies in the Gazzetta Ufficiale.

Source: From 1996 to 2006: Relazione Trimestrale di Cassa of December; from 2007 to 2010:

Relazione Unificata di Economia e Finanza Pubblica, both on data from the State General Accounting Department.

These figures, mainly meant to give domestical reasons for the government's budget proposal, often appeared quite different from those later published by the European institute of statistics (Eurostat) - even of the consolidated accounts. The Italian governments' optimism becomes especially evident in forecasts usually ascribed to increases in the domestic aggregate demand without further explanations.

Such bias is especially concerning. Estimated growth rates influence the expectations about revenues and expenditures, hence about the financing need: thus, budgetary decisions based on optimistic assumptions underestimate the risk of deficits (IMF 2007). Moreover, exceedingly confident forecasts indicate an irresponsible financial budgeting, in which precautions are neglected so as to accommodate a wider array of distributional demands (Hallerberg et al. 2009).

Further evidence that, until recently, Italian financial decisions had been irresponsibly open to special interests comes from Figure 4. Here, the gap is displayed 


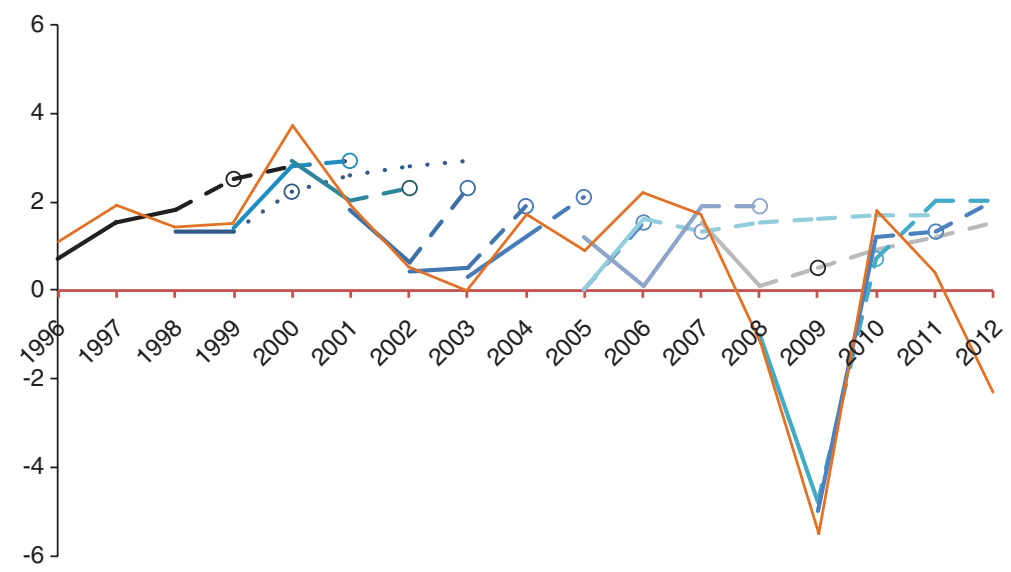

Figure 3: Italy's GDP, Estimated Annual Increase.

Keys: Solid lines=consolidated values; dashed lines=estimated values; empty dots=estimated value of reference for the financial decision.

Source: Continuous series: Eurostat database; 3-year and 5-year data: Relazione Provisionale e Programmatica (up to 2010), Documento di Economia e Finanza (from 2011) on data from ministerial Departments.

between the aggregate planned spending that the government agreed with line ministries and agencies before parliamentary debate, and the one that later passed into law. In Figure 4, then, the difference between what was proposed and what passed can be ascribed to the parliamentary stage alone of the budgeting process.

The gap proves that the debate always increased the total expenditures although each aggregate contributed differently to the overall dynamics. While cuts were passed to the fiscal allocations to the central bodies (the most relevant of which in 2007 , of $-2.9 \%$ with respect of the executive's proposal), as well as to the debt service (with the maximum of $-3.2 \%$ in 2004), the transfers to local and regional governments always hiked up (with the maximum in 2007 of $+22 \%$ with respect of an especially austere proposal).

Together, these data portray a decision-making process kept vulnerable to demands for further spending - demands which, according to Figure 4, parliamentary dynamics went along with and which, according to Figures 2 and 3, the executives were unable or unwilling to restrain. Little surprise that the Italian fiscal governance had thus proven incapable of rescuing the budget from the "tragedy" that dooms every common pool resource when its consumption is improperly regulated (Hallerberg et al. 2009).

Yet, if one takes into account the number of institutional reforms that the Italian fiscal policy had undergone in the past decades, such conclusion sounds puzzling if not unfair. What, then, has not worked? And what improvements are needed? 


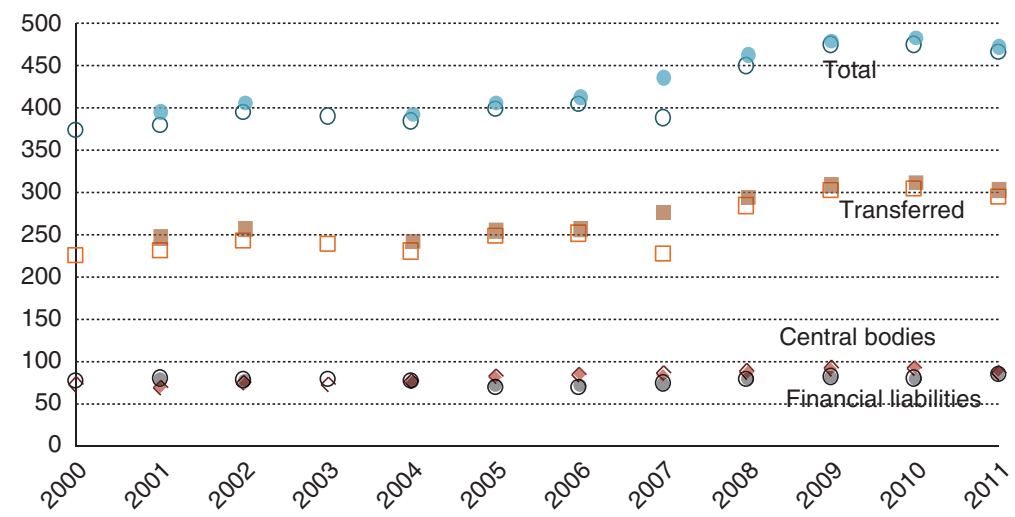

Figure 4: Italy’s National “economic budgets": Presented and Passed by Aggregate Expenditure (2000-2011, bln Euros at market prices).

Keys: Empty indicators=proposed expenditure; solid indicators=passed expenditure. Note: From 1999, the "national economic budget" is made of separate spending macro-aggregates. That of the "central bodies" includes personnel, management, overtime, allowances; "transferred" expenditures cover investments and the running costs of regional and local governments; "financial liabilities" account for the overall debt service. Until 2002, the spending of the constitutional bodies was separated from that of the other central bodies; in the figure, the two are aggregated for the sake of comparability. Similarly aggregated are the reserve funds, separated since 2004 .

The passed budgets for the years 2000 and 2003 are unavailable; the ones before the year 2000 are hardly comparable because of the outlays aggregation in use.

Source: State General Accounting Department.

In answering these questions, this article assumes a rational choice perspective because of the heuristic and prescriptive gains it allows. Section 2 discusses the institutional models that are believed effective, and the conditions for their functioning. Section 3 focuses on the Italian reforms to identify which model inspired them and why it did not deliver. Section 4 discusses the reasons why the recent European fiscal compact can provide a more fruitful direction for institutional reforms. Conclusions are drawn in Section 5.

\section{Fiscal Irresponsibility: Causes and Solutions}

According to the rational choice theory, fiscal irresponsibility occurs whenever elected politicians make an opportunistic use of public revenues, that is, deliver short-term benefits to special constituencies while dumping the costs on the public debt (Buchanan and Tullock 1965; Weingast et al. 1981; von Hagen and 
Harden 1995; Poterba and von Hagen 1999). As such, it marks the fiscal "state of nature" in democratic systems, where electoral competition requires politicians to maintain and widen their consensus. Left to the dynamics of "raw politics" alone, when in office politicians thus tend to drain budgets so as to lure voters and prevent future policy reversals, while debt allows them to delay and blur the issue of who should pay these benefits back.

Rational choice, however, assumes that such natural mechanism can be defused, if opportunism is constrained by proper governance designs. Indeed, empirical analyses have identified two effective types, "delegation" and "contract" (Hallerberg and von Hagen 1999; Hallerberg 2004; Hallerberg et al. 2009), which can neutralise irresponsibility alike - although each relies on different defusers, has different requirements, and shows different weaknesses.

The delegation type develops along the lines of the British case, and revolves around a negative defuser of opportunism - that is, the reduction in number of the decision makers. The "political property rights" over budgeting are here concentrated into the Ministry of Finance, that is into the only decision-maker without a constituency to serve but the taxpayers - which structurally guards her from the political incentives to opportunism. With the only support of her offices, on the basis of realistic estimations of future economic trends and of the governments' goals, the Minister first sets the national distribution of fiscal benefits and costs, then shields such "optimal budget" from the pressures of special interests. During the legislative process, moreover, those pressures conveyed by parliamentary groups are restrained by rules that either limit the Houses' power to amend the budget proposal, or that make variations in the financial envelope into a motion of no-confidence in the government. Similarly, in the post-legislative stages opportunism is defused by the power that the Ministry of Finance is given over administration - to stop misspending, as well as to discipline runaway agencies and line ministries.

Basically, the fiscal decision is here kept on the track of responsibility thanks to a "benevolent dictator." To the extent that the budgeting process is entirely maintained within the Finance Ministry's discretion, theory expects it to not yield to short-term consensus. Such an entrustment however requires that the parliamentary majority agrees with any use of fiscal discretion that the Ministry of Finance can make. As such, it better suits disciplined singleparty governments, or coalition governments with highly homogeneous fiscal preferences. Delegation is an especially efficient institutional design, as power concentration makes the Ministry of Finance capable of prompt responses even to sudden economic crises. However, the proper functioning of this governance model can be undermined by political crises - when 
parliamentary whips lose their ability to maintain functional and territorial demands within the limits of party and coalition discipline or, more generally, when the trust relationship between the majority and the Ministry is seriously challenged.

Conversely, the contract type derives from the Dutch case, and revolves around a positive defuser of opportunism - a binding, transparent framework agreement among multiple decision-makers. The type assumes that the heterogeneity of fiscal preferences in parliamentary majorities is irreducible, so that nobody can be trusted to decide unbiasedly on fiscal matters. Thus, a common distributive framework has to be agreed upon beforehand. The resulting coalition pact hence takes the form of a mid-term program where - on the basis of prudential estimation of future trends - negotiated policy goals and performance are made clear, public and measurable. These numeric indicators serve both as the yardsticks against which the legitimacy of distributional demands can later be gauged, and as restraints to the discretion of line ministries and agencies. Once the coalition has the policy goals set, the annual decision simply fine-tunes the fiscal means. Opportunism is then avoided thanks to the publicness of indicators and the widespread obligations to account for achievement. In each stage, mutual control closes the door on irresponsible decisions.

In such model, special pressures are not kept at bay; rather, they are disciplined, as their influence on the financial decision is contingent on how they fit the coalition pact. To the extent that all the policymakers move within the numerical targets and let their behaviour open to scrutiny, the contract type can thus secure fiscal responsibility even of porous processes in plural contexts. However, such governance design is less capable of adaptation to unforeseen economic conditions. Indeed, prudential estimations can result into surpluses and cushion a shock in the short run; yet, when the magnitude of a crisis is such that the policy contract proves untenable, the re-negotiation of priorities and targets may take too long for timely responses.

The models of contract and delegation together imply a worth theorisation of fiscal irresponsibility because of a twofold reason. First, the theory's pars destruens treats the tragedy of the fiscal common less as a pathology of the political system than as the natural result of unrestrained "raw politics" and parliamentary dominance, which can be prevented by proper institutional designs. As such, it rejects cultural or historical deterministic positions, and makes room to the possibility of policy shift and learning instead. Second, its pars construens does not provide a single best solution, but two, each suitable under alternative system conditions. Thus, it advances prescriptions that are sensitive to contexts and to the principle of adequacy. 
Moreover, that learning can succeed if solutions are adequate to the context is an especially consequential point. As Hallerberg et al. (2009) highlight, opportunism follows ineffective fiscal governance - i.e., designs that either adjust to raw politics or enforce the wrong discipline. Thus, relevant to the understanding of Italy's irresponsibility is not simply how far the case has moved from the state of fiscal nature, but also in which direction. This is the question to which the next section will provide an answer.

\section{Fifty Years of Reforms - How Proper?}

In the first season of republican budgets, the Italian fiscal decision-making was governed by the constitutional provisions alone. Article 81 on the one side gave the right of initiative to the executive, yet refused to recognise it a super-ordered position to the parliament; on the other, it conceived of the finance act as a yearly bookkeeping decision about non-mandatory spending, specifically made to close the gap between outlays and receipts. To secure a balanced budget was thus an issue to be handled by sectoral acts, each required to provide proper coverage to new expenses.

The constitutional rules however fell onto a context where the rationale of raw politics prevailed. Preferential voting and the proportional electoral system strongly tied the elected officials to special constituencies. The financial act was given no special status, so that the consensual rules in use for scheduling ordinary proposals applied - as well as secret vote and filibustering. Log-rolling and pork-barrel became common practices that the executive went along with, due to its fragmentation, its increasing economic competences, and a budget horizon limited to 1 year. The whole design thus promoted an opportunistic use of public finance (di Palma 1977; Pasquino 1993; Capano and Giuliani 2001; Jessoula 2012) that the Court of Auditors could not restrain. ${ }^{2}$

In such context, the need to change the fiscal governance already arose in the 1960s, and triggered a reform process as incremental as wide, which for decades has been unfolding at multiple levels - procedural, organisational, institutional (Ceccanti 1998; Verzichelli 1999; Vassallo 2000; Fabbrini 2003; Perna 2008; De Giorgi and Verzichelli 2008; Goretti and de Ioanna 2008; Goretti and Rizzuto 2010).

2 Detected since the early 1960s, especially with respect to multi-annual spending, the problem of resource inadequacy generated an enduring tension between the Court of Auditors and the Constitutional Court. In 1966, the latter's sentence no. 1 put an end to it by establishing the obligation to provide explicit coverage to multi-annual spending, yet considering debt as a legitimate means (della Cananea 1997). 


\subsection{The Direction of the Shift}

First interventions focused on the shape and contents of the fiscal decision-making. Law no. 62 of 1964 packed the many fiscal micro-decisions previously spread along the whole year into a single annual act, to be discussed in autumn. The single act included both an overview of the expenses of the year and the financial framework for the next one. In 1967, Law no. 48 changed the nature of such act from a neutral bookkeeping exercise into a strategic decision, functional to the executive's economic goals. The financial framework followed a mid-term planning document in which the executive gave reason for its fiscal decisions. Such planning was presented to the Houses by the Ministry of Budget, which the same Law re-named "Ministry of Budget and Economic Planning," supported by two new independent offices - for the analysis of mid- to long-term trends (Ispe), and of the state of the economy in the short-term (Isco). The new Ministry was also given a co-ordinating position within the executive, and had to provide a permanent secretariat to the new inter-ministerial committee for planning (Cipe), the collegial body of the ministries with economic portfolios. It was the Cipe however, and not the Minister of Budget, to be entrusted with the definition of guidelines, short-term interventions, and administrative mandates that detailed the planning. The reform thus sorted little effects on opportunism not only because it left the parliamentary dynamics and incentives untouched. In the executive it also contributed to the blurring of responsibilities and to the loosening of an already weak hold on the bureaucracy, as far as almost independent inter-ministerial committees proliferated to govern special policies - among the others, industrial, foreign trade, transport, price, credit. Moreover, the planning activities were decoupled from the monitoring and management of cash flows - the latter being under the control of the Ministry of Finance and, within it, of the State General Accounting Department. Law no. 48 of 1967 did not build any special relation between the Ministry of Budget and that of Finance, simply prescribing that the two had to co-operate - once again leaving the actual terms of their interplay to raw politics.

Ten years later, Law no. 468 of 1978 tipped the balance in favor of the executive and, within it, of the Finance Ministry. The "Forecasting and programmatic report" (Fpr) was added to the early stages of the budgeting procedure, to make the connection clearer between the draft provisions, the analysis of state of the economy, and the conditions of the public finance as by the Accounting Department's data. If such knowledge base increased the substantial legitimacy of the executive's proposals, it sorted little disciplining effects on the parliament's fiscal discretion: Law no. 468 also added a new decision to the procedure, the so-called "financial law," amending which the parliament could "update" 
the executive's proposal and, as a consequence, the whole planning. These "updates" usually passed without proper evaluation of their impact on the fiscal trends, and easily resulted into over-expenditure. However, Law no. 468 deeply altered the meaning of the amounts that the assembly passed, too. From immediate disbursements, such amounts became ceilings under which the bureaucracy had to move; also, actual paying was conditioned to the permit of the Ministry of Finance - in reality, of its Accounting Department. The Ministry of Finance was also given the capacity of operating adjustments during the fiscal year, so to secure coverage. The new fiscal governance thus set the financial law as the actual stake of a game still played by the rules of raw politics, of which the Ministry of Finance became the ultimate fixer - squeezed between the drifts of the bureaucracy on the one side, and the pressures from line ministries and parliamentary groups on the other.

From the end of the 1980s, new provisions strengthened the position of the executive in the process to the point that many saw a true regime change in them - from consensualism to "functional majoritarianism." Law no. 362 of 1988 contributed to the shift by constraining the amending power of the parliament - for instance, by requiring the financial envelope be voted before the single outlays were debated. Also, to the early stage of the budgeting procedure the "Document of economic and financial programming” (Defp) was added, which widened the contents of the Forecasting and programmatic report and put them in a European perspective. Through the Defp, Law no. 362 intended to make fiscal policy into an instrument for achieving macroeconomic goals consistent with the newly established Community ends. It also prescribed cost-benefit analysis in support of fiscal decisions - though such evaluation would never institutionalize. Even more relevant to the regime change was the sterilization of the amending power that the parliament itself decided by changing the Houses' Rules. As from 1983, a special session was instituted to pass the budget. In it, pre-defined time allocation and limits to debate aimed to prevent both scheduling games and filibustering. Also, secret vote was ruled out. Moreover, the Speakers were given the power to debar those amendments which proved inconsistent with the balancing of the budget. All in all, constraints were thus provided to log-rolling, which had made the fiscal law into a heap of heterogeneous interventions. Yet, despite of these changes, the parliament did maintain meaningful powers. The relevant decisions were increasingly debated as a different piece of legislation, the so called "related provisions," to which the rules of the budget session once again did not apply. In response, the executive reinforced its position in the post-legislative stages by an increasing recourse to decrees to operate on fiscal trends, and to "special funds" to allow for expenditures of its concerns - thus partially circumventing the parliament. 
In the 1990s, the regime change institutionalized. The electoral reform of 1993, reinforced in 2005, abolished preferential voting and promoted the competition among two coalitions, so affecting the dynamics within the parliament as much as the relationship between the parliament and the executive. On the side of the parliament, the reform clearly established a majority and an opposition, and informed appointments and scheduling to the rationale of spoils. Though, it could neither reduce the political fragmentation within the Houses, nor increase the homogeneity of fiscal preferences within any coalition. Many members of the majority from different parties still found reasons for amendments, that the executive counteracted by increasingly calling votes of confidence so to keep the session within its time limits, and the contents stuck to the original draft. The executive's ability to force the process followed the electoral reform as much as the reshuffles it underwent. Many inter-ministerial committees were abolished, the system of funds streamlined, and different fiscal and budgeting portfolios brought under the single "super-ministry" of Economy and Finance (Mef). Also, the two institutes for economic analysis Ispe and Isco were first merged, then neglected and eventually closed down by the Mef as "useless agencies" in 2010 - when their competences definitely passed to the Mef itself and to the national institute of statistics (Istat). Such concentration structurally unbalanced the relationship between the Mef and the parliament in favor of the former. Law no. 208 of 1999 contributed to the asymmetry by further reducing the parliament's room of maneuver: in timing, as it established that all the obligations of the budget session had to be fulfilled in the second half of the year; in contents, as the budgets of regional and local governments came to be decided of as transfers, and to be governed by the numerical rules of the Internal stability pacts - managed and monitored by the Mef itself. At the same time, Law no. 208 restored the relevance of the financial law, resolving that its provisions could intervene on previous sectoral legislation if such changes improved the budget balance. This had often been understood as an authorization to increase expenditures and trigger economic growth - although, for such increases to be proposed, their positive effects or sustainability had not to be proved.

Of the demands so legitimated, the Mef again was the ultimate fixer thanks to two related factors. First, the Ministry is where the knowledge and power are concentrated to draft the budget and account to Europe, as required by the membership to the Euro-area. Indeed, the Ministry of Economy and Finance incorporates both the Accounting Department and the Finance Directorates - that is, the key permitting, monitoring and forecasting functions. Second and consequent, the Ministry has grown into the actual gate-keeper between the positions of the majority in the parliament and those of the European Commission - hence, the one who can reconcile them or exacerbate their incompatibility instead. Indeed, 
the Mef is responsible of both the documents supporting the domestic fiscal decisions and those addressed to the European partners that account for planned reforms. Interestingly enough, not only these documents have long been issued at different times of the budgetary process, but often their contents differed one another and from the final equilibrium set by the parliament in December or later. So, little surprise that, on spring, adjustments were often due to make the cash flows fit the European commitments.

\subsection{Stability Beneath Change}

Over 50 years, reforms have thus incrementally as relentlessly moved the Italian fiscal governance toward the delegation type. Yet, the concentration of the budgeting capabilities in the executive, and the parallel reduction of the parliament's room for maneuver, has proven unable to sterilise the incentives to opportunism and institutionalize fiscal responsibility. Being this the result, the reason can only rest on those basic dynamics unaffected by the reforms. The experience that two privileged as expert witnesses had of the budgeting process is especially useful in casting a light on such dynamics.

According to them, irresponsibility generates at the very beginning of the budgeting process, when the financial requirements are estimated. This stage

begins in spring, with the agencies' requests to the State General Accounting Department for increasing future appropriations. Line Ministries feel little responsibility of it and are seldom aware of [such] requests ..., always incremental so that often, when toted up, they exceed the available resources of many dozens of billions of euros. In this stage of the process there is not a place where availability can be discussed. The Accounting Department lacks competences and interest to evaluate the substance of the spending programs, as well as to engage in a dialogue with the agencies: its doings are limited to the management and control of the single allocations, and to the exercise of its powers of permit, forbiddance and control. From its perspective all outlays are equal, the only cuts are linear, and the only possibility of reducing the deficit rests on raising taxes, tickets and so on. ... Even more complex is the problem of estimating the regional and local expenditure. Information is uncertain. ... Once again, the Accounting Department handles the problem through constraints, caps, cuts and the like without being capable of discriminating between different situations, in a context of bilateral negotiations with regions, provinces and municipalities according to a faction-like rationale. The consequence is a high rate of contentiousness and conflict, later destined to dump on the parliamentary debate (Pisauro and Visco 2008: pp. 141-142).

In the following stage, which unfolds within the cabinet, the budget is defined through bilateral negotiations first, then collectively. Despite the direct involvement of the line Ministries and of the Mef, the responsibility is still lacking, as 
it is inevitable that those ministers who are politically stronger or closer to the Finance Minister get a special treatment. Other negotiations, less evident yet maybe more effective, take place between the Accounting Department and single agencies (or parts of them). ... When the financial draft gets to the Council of Ministries, a marathon of many hours starts, with all the line Ministries bargaining with the Finance Minister who, once again, does not master every issue thoroughly and is provided with little instruments of defense (but to say 'no' to everybody, thus arousing their wrath). As far as he is concerned, the Prime Minister is little informed and unable to guide decisions. Also, he does not want to antagonize any line Ministry too much - and less than ever, in a coalition government, any leader of the major parties. The ... financial draft is smoothened and corrected and eventually approved. But the reality is, no one or very few really know what they voted for, and nobody feels especially obliged to any restraint (ibid.: p. 142).

When the draft gets to the parliament for consideration, hence,

the line Ministries bustle to mobilize the Members of the competent Commissions so to propose and pass favorable amendments at the expense of their colleagues, or better of the public finance. The members of the parliament, on their part, seldom have a complete and cognizant picture of the fiscal decision and, in any case, are little interested to it. They know (or are afraid) that the decision will eventually pass by a vote of confidence, so they focus on changes at the margin and mainly on issues of concern of their constituencies .... They do not want to waste their time debating and voting anything else. Especially when local or regional interests are at stake, representatives from government and opposition parties coalesce in fleeting majorities - the opposition being ready to agree on any amendment that outvotes the executive. The executive conversely needs the Parliament to pass all these provisions that put its programme into action. ... It is left with no choice ... but to mediate, endure and get ready for a vote of confidence (ibid.: pp. 142-143).

Such detailed picture shows that the reforms did not deliver because they proved unable to shield the budgeting process from the rationale of raw politics, which is deeply embedded in the administrative dimension. Also, the picture casts doubts on the validity of the delegation type of fiscal governance - at least, of a reading that makes fiscal responsibility depend on the concentration alone of budgetary capabilities into a single body within the cabinet. In the Italian case, such concentration did occur: yet, in so doing, the ownership of the process had been given less to the Finance Minister than to the State General Accounting Department. And the information asymmetry that the Accounting Department maintains with its parent ministry, then the cabinet, and finally the parliament is remarkable indeed. The Department is the only that really masters the details of the national expenditures - and the only capable of drawing up the financial law, too. It is hence the true addressee of pressures, and the one that can accommodate them. However, the Department has also been kept incapable of evaluating expenditures on their merits - which it instead treats on the basis of political closeness when necessary. The State General Accounting Department thus fully exerts its 
ownership of the process from the perspective of bookkeeping - the false neutrality of which makes room to irresponsible demands. It is hence the mix of bookkeeping rationale and raw-political criteria of decision about expenditures that, together, generate the conflicts which the bargaining in the cabinet can provide a fleeting fix, and that later go off in the parliament. Basically, irresponsibility stems from the combination of enduring irresponsible pressures and opaque distributional criteria in budgeting that the Accounting Department maintains - a mechanism that the regime change left untouched.

Such reading of Italian ineffectiveness entails a further theoretical consideration: even under the concentration of fiscal powers, responsibility cannot be delivered unless the central budget authority, and the bureaucracy, are held accountable for it. If such accountability is due from elected officials only, then the governance design can deliver only under condition of a clear widespread electoral mandate for fiscal responsibility that the delegation type can enforce and the next election can reward. Yet, the Italian political and social context is intrinsically plural especially as for fiscal preferences, to the point that even a majoritarian exercise has proven unable to compress them. Under such conditions, political accountability for fiscal responsibility becomes an erratic exercise of rhetoric unless a contract is provided. Thus, the inability of the new design to deliver can ultimately be ascribed to a reform strategy inadequate to the context. A more effective solution hence rests less on some further strengthening of the delegation model than in the shift toward the alternative type. And it is in such alternative direction that the European Union is currently pushing the Italian fiscal governance.

\section{The European Union as a Push Factor}

That the contract type can be an especially productive model for national reforms is a belief shared by the European institutions, too. To them, the priority is the stability of the Euro-area, hindered by two phenomena only partially overlapping: on the one side, the enduring fiscal irresponsibility of some Members; on the other, the low convergence of national macroeconomic and fiscal policies. And it is from a very "Dutch" perspective that the recent Fiscal Compact ${ }^{3}$ addresses these problems.

3 That is, the "Treaty on Stability, Coordination and Governance in the Economic and Monetary Union," signed in 2012 which reformed the previous "Stability and Growth Pact," enforcing the Treaty of Maastricht on the Economic and Monetary Union. 


\subsection{European Provisions for Institutional Change}

In order to increase the binding force of the European constraints, the Compact and the related provisions intervene mainly on the procedural dimension, so to couple the domestic budgeting processes to the European decisions more tightly. Downstream, now the Union requires the Members to link their expenditures explicitly to the common goals of Europe 2020 - the strategy for a "smart, sustainable and inclusive growth" ${ }^{4}$ which continues the Lisbon strategy. Upstream, the European Commission instituted the so-called "European Semester" during which a technical dialogue takes place with the national authorities about the knowledge base of the domestic budgeting process - so to secure it is compliant to minimal standards, and later used for fiscal decision.

The Compact then considers expenditures and revenues less as normative elements of domestic social pacts between governments and their citizens than - pragmatically - as policy tools through which the national system can improve the performance of relevance to the European membership. Directive 85/2011/EC, which anticipated many of the Compact's provisions, requires that national planning makes out clear the reasons beneath the choice of instruments, their setting, and their short-, mid- and long-term financial effects under different scenarios, as well as the non-financial effects. The Directive also commits the Member states and their subnational authorities to make a transparent and accessible use of both the data and the methods to prove the effectiveness and the sustainability of their expenditure and revenues over time - so that the executive's reasons can be contested at the European as well as at the domestic level. The prescription is made binding by the provision that, in case of non-compliance, the Commission herself will provide the knowledge base for the national fiscal decision - which would actually put the national government under receivership.

The enhanced fiscal governance so draws incentives that press each Member country to equip with a proper performance budgeting, and to make the performance measures into key elements of the budgeting process at every level of government. As such, it mainly operates on the accountability side of the national fiscal governance and relies on the logic of the contract type to close the door on irresponsibility.

4 The strategy revolves around substantive output or performance targets in five policy areas employment, education, research, energy innovation, social inclusion - that the national governments are committed to achieve. See COM (2010) 2020 fin, and the European Commission website http://ec.europa.eu/europe2020/index_en.htm 


\subsection{So Far, is Italy Changing?}

Italy has promptly aligned with the European prescriptions of the Fiscal Compact, in some case even anticipating them. At the same time, it has understood its contents quite peculiarly.

Law no. 196 of 2009 and following modifications intervene on the whole of the decision-making process, especially on the point of transparency in planning. The Defp is so replaced by the new «Decision of Public Finance» (Dpf), whose contents are organized and developed according to the European prescriptions. Although its capacity to constrain the following decision-making still proves weak, the Dpf however puts an end to the practice of the executive's double and different justification of its budgetary decisions - to Europe and to the parliament.

Moreover, to improve the knowledge underlying the financial decision, Law no. 196 prescribes the standardization of the many accounting practices that the governments and public enterprises at different levels were previously allowed to maintain. The new «Integrated bookkeeping plan» defined by Legislative Decrees no. 91/2011 and no. 118/2011 also obliges all the bodies of the public sector to organize their budgetary data alike, according to the European criteria established for calculating public deficit and debt, and to supply them electronically to the State General Accounting Department - which still remains the owner of the central databank.

Law no. 196 also requires the "missions" and "programs" of the budget to be organized according to the European classification of the functions of government (Cofog), previously used for statistical reporting to Europe yet not in the domestic budgetary process - in which the key reference had always been the legal basis of each item of expenditure. According to Law no. 196, the functional units of the Cofog are so meant to structure the parliament's votes, thus reducing them to a manageable amount of less detailed decisions; but also to facilitate agencies' accountability, as missions and programs are to be associated to functional outcomes and outputs.

Legislative Decree no. 123/2011 completes the design of the new performance budgeting by complementing the usual control of legal conformity with evaluations based on "economic and statistical methodologies" so to improve the "efficiency" and "effectiveness" of spending. Such shift toward the contract type of fiscal governance involves the State General Accounting Department, too. The Decree gives it the responsibility of coordinating a network of "Units for analysis and evaluation" of the agencies' and public enterprises' spending; as a consequence, it pushes the Department to internalize new competences consistent with its coordination tasks, and different from classical bookkeeping. Yet the Decree also states that the total of personnel cannot increase - which conditions the change in the Department's competences to the pace of "natural" turnover. 
Also, the Evaluation Units are assigned general competences to "verify efficiency, effectiveness and adequacy" of allocations; yet, they have to report their results yearly to the line ministries, and only every 3 years to the parliament. In the shortterm, moreover, the Legislative Decree just required the Evaluation Units to see whether any mandatory expenditure could be reclassified as non-mandatory for cut, but without further opinion - while no performance indicator has still formally been attached to outlays.

At least in the short-term, thus, the reform does seem at risk to fall short of the European intentions - unless a "policy entrepreneur" intervenes to pull the institutional change on the track of the contract type of governance. And, again, the reform of 2009 actually provides such interest by design. After years of compression of its budgeting powers, the parliament is restored its position within the fiscal governance. Law no. 196 of 2009 requires the Mef to give yearly reasons of the enforcement of the performance budgeting to the Houses, so returning the ultimate political property rights on the reform to the parliament. Also, following the Law's "Measures for the transparency and controllability of spending," the parliamentary committees are required to produce observations and evaluations about the data and the methods used by the executive to draft the budget, as well as to contribute to the monitoring, control and scrutiny of the financial trends. For this purpose, the Law established the right of access of the House and the Senate to every databank and other relevant sources, as well as the obligation to the executive of publishing all its decisions. Law no. 196 hence fully recognises the parliament's power to intervene on the knowledge for budgeting, also providing it with the opportunity to draw informed amendments independent from interest groups and their knowledge.

This, however, is precisely just an opportunity. To make use of it, the parliament does require incentives and competencies. The enduring sensitivity of the public opinion and the voters toward waste can easily provide the former. The latter are lacking, instead (Regonini 2012).

True, the Constitutional Law no. 1 of 2012 - besides the constitutionalisation of the balanced budget, the obligation to agencies and subnational governments to contribute to it, and the definition of standard of accounting and statistics as exclusive competence of the central government - established "the institution in the Houses ... of an independent body with the task of analysing and scrutinising the budget trends and of evaluating the compliance with the budget rules" (art.5.1.f). This ruling, even if seemingly undecided between a monitoring and an evaluation function for parliament, can provide the missing piece of the new governance jigsaw. Whether the new Parliamentary Budget Office will make the Houses into the main accountee of the executive, or will play as the agent of the Mef into the parliament so to discipline its amending activity, or will even 
prove of little use but symbolical, it cannot however be said yet, as its board was appointed only on April, 302014.

\section{Conclusions}

The Italian case shows how a remarkable effort to remove the political incentives to opportunism can result into a failure when made along the lines of an inadequate governance model. According to theory, nor the delegation neither the contract type can deliver if the bureaucracy is left free to drift from the financial decision; but only an explicit contract provides those constraints that can discipline pressures and drifts in the post-legislative as well as in the legislative stages of budgeting, by keeping all the players accountable to numerical performance indicators. When imposed to a structurally plural context, the delegation type hence proves ineffective: in itself, the concentration of budgetary capabilities does not guarantee that the budgeting process is effectively shielded from pressures, and that the benevolent dictator will not fall for the lure or the necessity of irresponsibility. That is why better performance is here deemed to descend from the adoption of the alternative type - a contract that structures the public budget around performance targets for which explicit accountability is due. The negotiation alone of numeric performance indicators, and the related evaluation of expenditures, can secure the identification and the debarring of opportunistic spending, and of the underlying short-terministic demands, as an ineffective contribution to policy success.

The activation of fiscal responsibility through contract in Italy however almost requires a reversal of the rationale followed by the previous institutional reforms. Such "governance by policy knowledge" implies that the political property rights on the budget, its targets, and the related evaluation criteria are given back to the parliament (Schick 2002; Stapenhurst et al. 2008). As far as fiscal responsibility depends on the criteria used to discriminate among pressures, constrain behavior and promote learning, the Assembly has a central role to play - less as subservient majority to the executive than as the arena where fiscal preferences are responsibly molded into the budget, and heterogeneous interests composed into shared binding goals. As a consequence of the previous attempts at sterilizing political incentives to opportunism, however, the Italian parliament is now put at disadvantage in the knowledge game. New institutional rules consistent with the contract rationale of the European enhanced fiscal governance do provide the opportunity of such reversal; so far, however, the opportunity remains on paper, as the parliament still lacks the resources to enter the domestic and international technical dialogue successfully. 
To fill the gap, the parliament hence should internalize the capabilities for influencing the definition of proper performance indicators; running independent evaluation of instrument effectiveness; scrutinizing the plausibility of the estimations beneath the executive's draft under different scenarios. The Parliamentary Budget Office theoretically provides a suitable solution - to the extent that it is properly designed, financed and staffed. Without this all, the last governance reform could remain a symbolic exercise unable to amend deeply embedded irresponsible customary practices - with the easy consequence of reinforcing an opportunism whose effects, however, appear less and less bearable.

\section{References}

Buchanan, James M. and Gordon Tullock (1965) The Calculus of Consent. Ann Arbor: University of Michigan Press.

Capano, Giliberto and Marco Giuliani (2001) “Governing Without Surviving?” Journal of Legislative Studies, 4:13-36.

Ceccanti, Stefano (1998) "Regolamenti parlamentari: un altro tassello di una «riforma strisciante»," Quaderni Costituzionali, XVIII(1):157-172.

De Giorgi, Elena and Luca Verzichelli (2008) “Still a Difficult Budgetary Process?," South European Society and Politics, 1:87-110.

della Cananea, Giacinto (1997) "The Reform of Finance and Administration in Italy: Contrasting Achievements," West European Politics, 1:194-209.

di Palma, Giuseppe (1977) Surviving Without Government. Berkeley: University of California Press.

Fabbrini, Sergio (2003) “Rafforzamento e stabilità del Governo.” In: (Ceccanti, S. and S. Vassallo, eds.) Come chiudere la transizione. Bologna: il Mulino, pp. 205-224.

Goretti, Chiara and Paolo de Ioanna (2008) La decisione di bilancio in Italia. Bologna: il Mulino. Goretti, Chiara and Luca Rizzuto (2010) "Il ruolo del parlamento italiano nella decisione di bilan-cio," Seminario Banca d'Italia, http://www.bancaditalia.it/studiricerche/ seminari/2010/parlamento_italiano/goretti_rizzuto.pdf.

Hallerberg, Mark (2004) Domestic Budgets in a United Europe. Ithaca: Cornell UP.

Hallerberg, Mark and Jurgen von Hagen (1999) “Electoral Institutions, Cabinet Negotiations, and Budget Deficits within the European Union." In: (Poterba, James M. and Jurgen von Hagen, eds.) Fiscal Institutions and Fiscal Performance. Chicago: University of Chicago Press, pp. 209-232.

Hallerberg, Mark, Rolf Strauch and Jurgen von Hagen (2009) Fiscal Governance in Europe. Oxford: Cambridge UP.

International Monetary Fund (2007) Italy: Budget System Reforms, http://www.rgs.mef.gov. it/_Documenti/VERSIONE-I/Servizio-s/Studi-per-1/Documenti/Italia---Riforme-delsistema-di-bilancio---Testo-integrale-in-lingua-inglese.pdf.

Jessoula, Matteo R. C. (2012) "Ricostruzione postbellica e decollo delle pensioni." In: (Ferrera, Maurizio, Valeria Fargion and Matteo R. C. Jessoula, eds.) Alle radici del welfare all'italiana. Firenze: Marsilio, pp. 79-153. 
Pasquino, Gianfranco (a cura di) (1993) Votare un solo candidato. Bologna: Il Mulino.

Perna, Raffaele (2008) “Le procedure di bilancio, fra Governo e Parlamento, in una democrazia maggioritaria.” In: (Lippolis, Vincenzo, eds.) (a cura di) Il Parlamento del bipolarismo: un decennio di riforme dei regolamenti delle Camere. Napoli: Jovene, pp. 149-177.

Pisauro, Giuseppe and Vincenzo Visco (2008) "Note sulle procedure di bilancio," Politica economica, 2:141-158.

Poterba, James M. and Jurgen von Hagen, eds. (1999) Fiscal Institutions and Fiscal Performance. Chicago: University of Chicago Press.

Regonini, Gloria (2012) “Parlamenti analitici,” Rivista Italiana di Politiche Pubbliche, 1:33-87.

Schick, Allen (2002) “Can National Legislatures Regain an Effective Voice in Budget Policy?” OECD Journal of Budgeting, 3:15-42.

Stapenhurst, Rick, Riccardo Pelizzo, David M. Olson and Lisa von Trapp, eds. (2008) Legislative Oversight and Budgeting. Washington: The World Bank.

The Economist (1997) Italy's Back, 16 Ottobre, http://www.economist.com/node/102702.

Vassallo, Salvatore (2000) "La politica di bilancio: le condizioni e gli effetti istituzionali della con vergenza.” In: (Di Palma, Giuseppe, Sergio Fabbrini and Giorgio Freddi, eds.) Condannata al successo? L'Italia nell'Europa integrata. Bologna: il Mulino, pp. 287-323.

Verzichelli, Luca (1999) La politica di bilancio. Bologna: il Mulino.

von Hagen, Jurgen and Ian J. Harden (1995) "Budget Processes and Commitment to Fiscal Discipline,” European Economic Review, 3-4:771-779.

Weingast, Barry R., Kenneth A. Shepsle and Christopher Johnsen (1981) "The Political Economy of Benefits and Costs," Journal of Political Economy, 4:642-664. 